\title{
RISK ANALYSIS FOR SUSTAINABILITY OF OIL PALM SMALLHOLDINGS
}

\author{
Diana Chalil ${ }^{*}$ and Riantri Barus $\left.{ }^{*}\right)$ \\ *) Department of Agribusiness, Faculty of Agriculture, Universitas Sumatera Utara \\ Jl. Dr. A. Sofian No.3, Kota Medan, Sumatera Utara 20155
}

\begin{abstract}
Oil palm plantation is well known as a profitable business. In general, oil palm smallholders have a higher income than farmers of other commodities. However, most smallholdings have land sizes that do not reach the economic scale. Together with the lack of managerial skills, smallholdings are likely to be more vulnerable to production and price fluctuations, which in turn affects their business sustainability. This study was conducted to analyze the possibility and impact of production and price changes to the oil palm smallholdings' sustainability. Data were collected from 240 schemed and independent smallholders in Asahan, Labuhan Batu, Labuhan Batu Utara and Labuhan Batu Selatan, which were selected with purposive cluster sampling. The production and market risk possibility and impact were measured with Value at Risk Method. The estimations showed that smallholders had a low risk possibility and impact, which partly stemmed from the enormously low threshold of both production and market risks. In fact, on average, smallholders' productivity is less than $20 \%$ of the potentials, and many schemed smallholders receive low prices due to their aged trees. This may be harmful to smallholding sustainability. Since VaR only considers risks from variations of production and price, a low threshold is not considered as a risk for sustainability. Therefore, further studies using different thresholds or approaches are required. From the policy implication point of view, to address such a situation, the Indonesian government needs to improve smallholdings' productivity and their composition of trees.
\end{abstract}

Keywords: risk analysis, oil palm, schemed and independent smallholders, value at risk (VaR) model

\begin{abstract}
Abstrak: Perkebunan sawit dikenal sebagai usaha yang menguntungkan. Secara umum pekebun sawit mempunyai pendapatan yang lebih tinggi dibandingkan dengan petani yang mengusahakan komoditi lain. Namun demikian, sebagian besar perkebunan rakyat berukuran kecil dan tidak mencapai skala ekonomis. Ditambah lagi dengan kelemahan dalam ketrampilan manajerial, pekebun sawit rakyat menjadi lebih rentan terhadap fuktuasi produksi dan harga, yang pada akhitrnya mempengaruhi kesinambungan usaha pekebun tersebut Penelitian dilakukan untuk menganalisis posibilitas dan dampak perubahan produksi dan harga terhadap kesinambungan perkebunan sawit rakyat. Data diperoleh dari 240 pekebun sawit mitra dan mandiri di Asahan, Labuhan Batu, Labuhan Batu Utara and Labuhan Batu Selatan, yang dipilih dengan metode purposive cluster sampling. Posibilitas dan dampak risiko diukur dengan Metode Value at Risk. Hasil estimasi menunjukkan bahwa pekebun rakyat mempunyai posibilitas dan dampak risiko yang rendah. Namun demikian, nilai risiko yang rendah tersebut lebih disebabkan oleh penggunaan nilai ambang yang cukup rendah. Kenyataannya, rata-rata produktivitas perkebunan sawit rakyat lebih rendah $20 \%$ dari potensinya. Di samping itu, banyak pekebun mitra yang menerima harga rendah karena TBS mereka berasal dari tanaman tua. Kondisi yang demikian dapat membahayakan kesinambungan perkebunan sawit rakyat tersebut. Namun karena Metode VaR hanya menghitung risiko dari variasi produksi dan harga, maka ambang yang rendah tidak dipertimbangan sebagai risiko bagi kesinambungan usaha. Dengan demikian, kajian lanjutan dengan menggunakan nilai ambang atau pendekatan yang berbeda. Dari sisi implikasi kebijakan, untuk mengatasi hal tersebut, Pemerintah Indonesia perlu membantu meningkatkan produktivitas dan komposisi umur tanaman perkebunan sawit rakyat.
\end{abstract}

Kata kunci: analisis risiko, kelapa sawit, petani mitra dan swadaya, model Value at Risk (VaR)

\footnotetext{
${ }^{1}$ Corresponding author:

Email: chalildiana@gmail.com
} 


\section{INTRODUCTION}

Oil palm smallholdings have been developed since 1986. Initially the development was fully assisted by state and private companies. However, a decade later, triggered by the profit enjoyed by the schemed smallholders, independent smallholdings started to develop. However, they have neither applied the same cultivation treatment nor the certainty of the same sale. As a result, independent smallholders' productivity and selling prices are more fluctuated, indicating their higher production and price risks. Previous studies show that smallholdings' productivity varies from 0.23 to 4.49 tons of $\mathrm{CPO}$ per hectare, and 10.20 to 18.53 tons of FFB per ha, with independents having a lower level than the schemed smallholdings (Directorate General of Estate Crops, 2017; Chalil and Barus, 2016). Without a partnership, the independent smallholders also receive fluctuated selling prices, especially in the low and high production seasons, that can reach as low as IDR1,075 (USD0,08) and IDR1,724 (USD 0,125), respectively (Chalil and Barus, 2017). Most of the independent smallholders' bargaining power is also weak because they need to sell their harvest within 24 hours to big company processors, as the Fresh Fruit Bunches (FFB) is not an end product and is perishable. In addition, more than $75 \%$ of the Indonesian palm oil is exported (BPS, 2010-2015), creating a long supply chain with smallholders at the bottom of the chain. With the fluctuations and the variations in the level of production and selling prices, smallholders' income varies considerably, from IDR1,021,000 IDR11,367,333 or USD73.81 - USD821.81 per ha per semester. In fact, oil palm smallholdings involve approximately 2,165,305 households (Directorate General of Estate Crops, 2017) and have contributed $3.47 \%$ of Indonesia's GDP (Pusdatin, 2015). While the development of oil palm smallholdings has been defined by the Indonesian Coordinating Ministry for Economic Affair (Kementerian Koordinator Bidang Perekonomian, 2011) as a provision of employment and poverty alleviation in rural areas, the production and price risks might inhibit the achievement of the program.

Based on the indications described in the background, the problems of this study can be formulated as follows:

1) The sources of production and price risks of oil palm smallholdings in North Sumatra. 2) The possibilities and impacts of the production and price risks of oil palm smallholdings in North Sumatra.
Risk is often related to uncertainties. There are two common risk measures: probability and impact. In general, people will avoid a severe risk impact although having a small probability (Howard, 1988) Probabilities and impacts can be objectively estimated, which should cover both the basic risk and catastrophic losses (Wang et al. 2010). However, farmers' risk management is also influenced by their perceptions, which are often subjective (Ogurtsov et al. 2008; Aimin, 2010; Köprülü, 2014). These explain the division of risk into objective and subjective risks (Turvey et al. 2013). In other words, the objective risk is calculated based on facts and historical data, while the subjective risk is determined by the decision maker's beliefs and values (Hansson, 2010). Even the subjective risk could be calculated with the same method applied to the objective risk calculation. In addition, beliefs and values may also be influenced by the farmers' knowledge.

Higher income often follows with higher risks. In agricultural products, this refers to cash crops and market oriented products. These products need to be monoculture to reach an economic scale and need to accommodate the consumers' preferences in the market; however, monoculture may lead to higher risk. In diversification, smallholders that have more than one commodity can have various production and price fluctuations, in which production or price decrease in one commodity can be covered by other commodities. Therefore, cash crop smallholders will deal with higher risks. In fact, both subsistence and commercial farmers have to deal with risks, including production, market, financial, politics or human and personal risks. However, their strategies to handle risks are different. Subsistence farmers chose diversified crops, storage facility and avoiding debt, while commercial farmers chose to apply more pesticides, monitored market prices, contract farming, and diversified sales channels, saved money, and select more profitable crops as their risk management strategies (Riwthong et al. 2016). Government interventions through policies can play important roles in improving the risk management strategies including those of the global supply chain. However, the process of the agreements between countries along the supply chain can in contrast amplify the price and market risks (Santeramo et al. 2014).

Girdžiūtè (2012) and Aimin (2010) suggest that the sources may be related to each other. Therefore, rather than assessing the different risk sources separately, farmers need to have integrated risk assessment to 
identify the interaction so that the risk management decisions will be faster and more efficient. With the improvement in technology, such as in the era of Internet of Things (IoT), these traditional risks are likely to be reduced. However, new risks emerge in all perception, network and application layers (Yan et al. 2017).

Most palm oil risk analysis is concerned more about environmental and social risk aspects rather than the economic risks (Lake et al. 2016; van Dijk, 2012). In fact, most smallholders can sustainably manage their business if they address the economic risks. This study was conducted as an effort to fill in the gap of the palm oil economic risks and covers: Analysis of the risk sources; Analysis of the risk probability and impact. The results are expected to give insights for stakeholders and policymakers to develop the palm oil industry, especially in supporting employment and poverty alleviations in rural areas.

This study analyzed both production and price risks for schemed and independent smallholders in 4 oil palm smallholding centers in North Sumatra. Data were based on smallholders' memory about their production and selling price fluctuation in 2016-2018.

\section{METHODS}

This study was conducted in Labuhanbatu, Asahan, Labuhanbatu Utara dan Labuhanbatu Selatan, which are the oil palm smallholdings centres in North Sumatra, with more than 14,000 to almost 37,000 smallholders in each district (Directorate General of Estate Crops, 2017).

Primary data were collected from 240 smallholders determined by cluster stratified sampling. The cluster was based on the management, and schemed and independent smallholders, while the stratification was based on the land size, $\leq 3$ ha and $>3$ ha. Risk data were collected by interviewing smallholders about their production and selling price over the past 3 years. All information was based on their memories, as no one had any record on them.

Risk was analysed using the statistical approach of Value at Risk (VaR) model, which had been broadly applied in previous studies (Asfaha et al. 2014; Saragih, 2018; Suharyanto et al. 2015). VaR estimates the maximum possible loss, $\mathrm{X}$, in the coming given period when given the normal market conditions and a certain confidence level, $\alpha$ (Wang et al. 2010). Risk probability was measured with $\mathrm{Z}$-score $=\frac{\mathrm{X}-\mathrm{X}}{\mathrm{S}}$, in which $\mathrm{S}=$ production or price standard deviation, $\mathrm{X}=$ production or price threshold, and $\overline{\mathrm{x}}=$ production or price average. Risk refers to the income decrease due to low production in dry season, or low prices during peak season. The threshold value was calculated with the Break Event condition, in which probability was obtained from the area of the normal $\mathrm{Z}$ distribution table. Risk impact was calculated with:

$$
\mathrm{VaR}=\bar{x}+\mathrm{z}\left(\frac{\mathrm{s}}{\sqrt{\mathrm{n}}}\right)
$$

Note: $\mathrm{S}$ (the loss standard deviation); $\overline{\mathrm{x}}$ (loss average).

Income was calculated with the cash flow approach. Average productivity and selling price were calculated with weighted average, considering the 3 months of shortage season and the 3 months of peak season. Initially, shortage season occurs from January to March or April during the dry season, while peak season starts from June to August during the rainy season. Currently the dry and rainy seasons change, so do the shortage and peak seasons. However, the duration is mostly the same, which is 3 month for each season and 6 months for the normal one. This study analysed both production and price risks based on their variations. Sources, probability and impact of the risks were indicated and calculated with details in Figure 1.

\section{RESULTS}

\section{Analysis of the risk sources}

The production decrease of oil palm trees can stem from seasonal conditions, fertilizer applications, pest or disease attacks, and management conditions. There are 2 seasonal conditions, namely, the shortage (trek) during the dry season and the peak season during the wet season. During shortage seasons, yield decreases and price increases, and vice versa during the peak season. Benny et al. (2015) study in North Sumatra, Jambi and Riau showed that in 2015 , oil palm productivity was significantly influenced by climate (rainfall, humidity and temperature), but not by topography and soil fertility. However, the impact could vary with the difference in soil condition. For example, in general oil palm production will be higher with higher rainfall; however, when the soil water absorption capacity is low and erosion rate is high, rainfall volume will be negatively correlated with the level of production. 


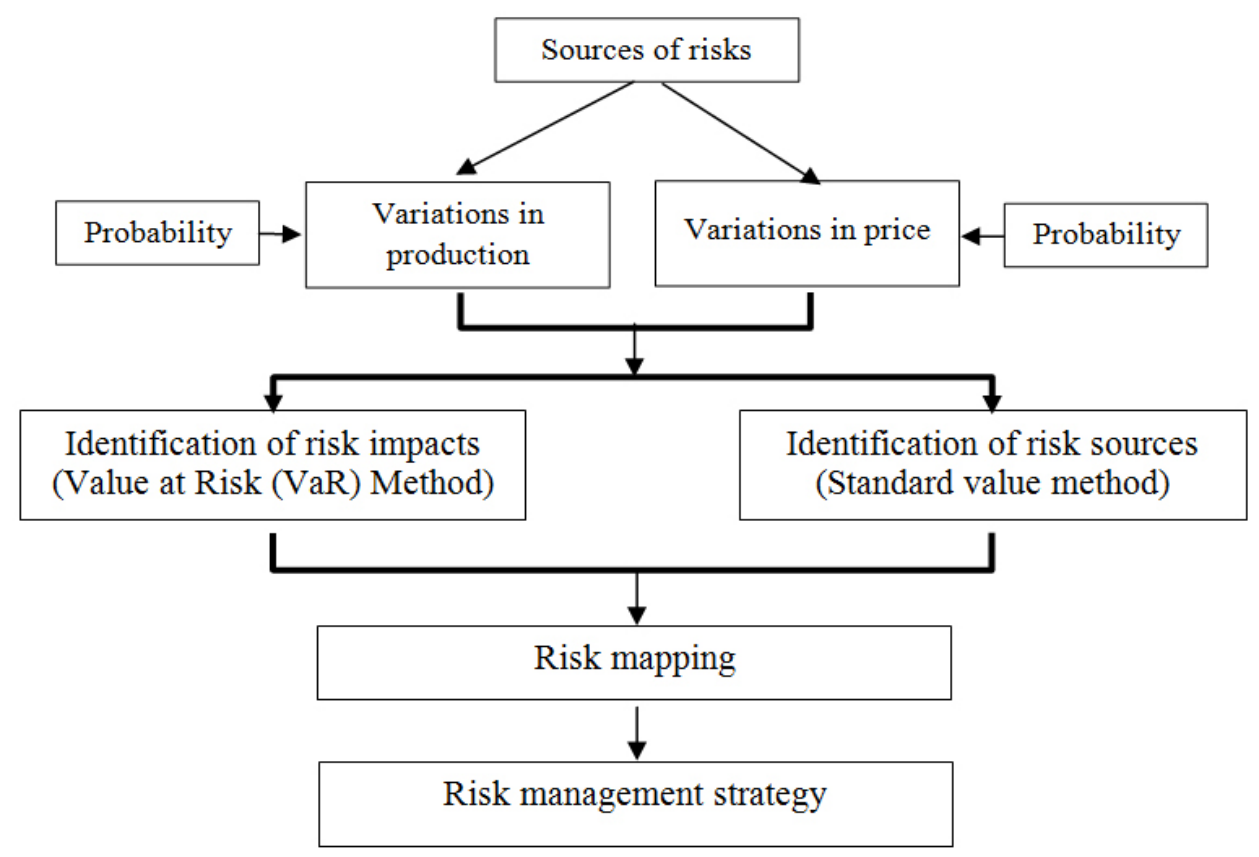

Figure 1. Research framework

Management type can be differentiated into schemed and independent. All schemed smallholders receive trainings or mentoring from state or private company staff; as a result, they tend to apply better agricultural practices and management in comparison to independent ones. In addition, with less financial support and access to production factors, many independent smallholders do not apply the appropriate amount and type of fertilizers. The recommended fertilization is 4 times a year, with dose and type in accordance with the age of the trees. However, the fertilizing frequency range of independent smallholders is zero to 3 times with high variations in dose and type of fertilizers. Schemed smallholders also have partnerships with companies, mainly for selling the Fresh Fruit Bunches to mills. With the Regulation of the Agricultural Ministry, the prices of schemed smallholders have reached minimum levels, which are based on the minimum shares of smallholders. The government price differs for FFB from oil palm tree with different ages. Therefore, unless the yields come from different tree ages, the selling price of schemed smallholders is relatively high and stable compared to the independent smallholders (Figure 2).

\section{Analysis of the risk probability and impact}

After taking out outliers, 66 schemed data and 124 independent data samples were used. Table 1 shows that both schemed and independent smallholders have low risk probability in production i.e. $11.22 \%$ and $4.73 \%$, respectively. Similarly, both also have low market risks i.e. $0.001 \%$ and $0.005 \%$, respectively. The risk probability is also low because the thresholds are low, as their production costs are also low. The biggest cost share comes from the labour expenditure, with an average of $52.14 \%$ and $53.73 \%$ of the schemed and independent total production costs, respectively. From the total labour usage, $31.29 \%$ and $32.92 \%$ of the schemed and independent smallholders' workers came from family workers, so they were not paid. In addition, $75.26 \%$ still used cheap illegitimate seeds, which can only reach $70 \%$ maximum production from legitimate ones, and most of them apply the less than recommended amount of fertilizers. Climate changes are also not extreme in North Sumatra, and pest and disease are still controllable. For schemed smallholders, the $0.337 \mathrm{ton} / \mathrm{ha} /$ month production threshold means that the minimum production they need is 4.044 ton/ ha/year, while on average they get $1.32 \mathrm{ton} / \mathrm{ha} /$ month or $15.84 \mathrm{ton} / \mathrm{ha} /$ year. However, the potential of the 22 year old tree yield with S3 land suitability is 21 ton/ha/ year. For independent smallholders, the 0.377 ton/ha/ month production threshold means that the minimum production is 4.524 ton/ha/year, while on average they receive $1.55 \mathrm{ton} / \mathrm{ha} /$ month or $18.60 \mathrm{ton} / \mathrm{ha} /$ year. In fact, the potential of 10-21 year old trees for S3 land suitability is 25 ton/ha/year (Table 2). 


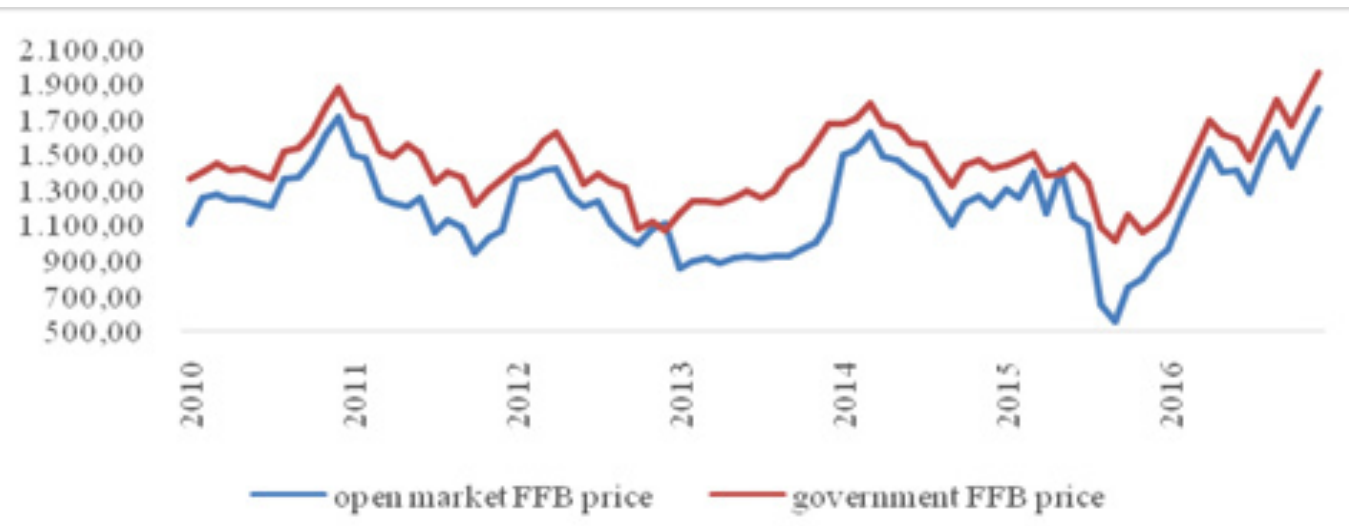

Figure 2. The Development of FFB Open market and government price

Table 1.VaR Analysis Results

\begin{tabular}{lcccc}
\hline \multirow{2}{*}{ Description } & \multicolumn{2}{c}{ Schemed $(\mathrm{n}=66)$} & \multicolumn{2}{c}{ Independent $(\mathrm{n}=124)$} \\
\cline { 2 - 5 } & production & Market & Production & Market \\
\hline Threshold & 0.338 ton/ha/month & IDR371.540/kg & 0.380 ton $/$ ha $/$ month & IDR349.099/kg \\
Z score & -1.215 & -4.291 & -1.671 & -3.897 \\
Probability (\%) & 11.224 & 0.001 & 4.732 & 0.005 \\
VaR (IDR/ha/year) & \multicolumn{2}{c}{$3,008,500$} & & \multicolumn{2}{c}{975,591} \\
\hline
\end{tabular}

Table 2. Smallholdings' characteristics

\begin{tabular}{lcccc}
\hline \multirow{2}{*}{ Description } & \multicolumn{2}{c}{ Schemed $(\mathrm{n}=66)$} & \multicolumn{2}{c}{ Independent (n=124) } \\
\cline { 2 - 5 } & Average & Range & Average & Range \\
\hline Income (IDR/ha/year) & $16,763,412.24$ & $1,077,000-38,857,600$ & $19,726,333$ & $4,422,000-38,857,600$ \\
Trees' age (year) & - & $4-41$ & - & $4-38$ \\
3-9 year (\%) & 12 & - & 14 & - \\
10-21 year (\%) & 31 & - & 59 & - \\
>21 year (\%) & 57 & - & 27 & - \\
Land size (ha) & 2.89 & $0.60-10.00$ & 2.74 & $0.30-22.00$ \\
Productivity (ton/ha/month) & 1.32 & $0.25-2.60$ & 1.55 & $0.50-3.00$ \\
Selling Price (IDR/kg) & $1,367.64$ & $1,100-1,700$ & 1389.60 & $1,000-1,700$ \\
\hline
\end{tabular}

Similarly, for schemed smallholders, the IDR371.54 (USD0.03) per $\mathrm{kg}$ price threshold is extremely low compared to the average price of IDR1367.64 (USD0.098) per kg. Even during peak season, schemed smallholders stillreceive an average price ofIDR1217.91 (USD0.088) per kg. For independent smallholders, the IDR349.099 (USD0.025) per $\mathrm{kg}$ is enormously low compared to the average price of IDR $1,389.60 / \mathrm{kg}$ and peak season price of IDR1,229.16 (USD0.088) per kg. In fact, palm oil market is relatively dynamic. Prices can change daily, but most smallholders are not directly involved in the market. Schemed smallholders sell their FFB to the mills of their partners, receiving a selling price close to the government price. Most independent smallholders, although having no obligation to sell to certain traders, usually sell their FFB to the same local traders. Therefore, smallholders rarely deal with market dynamics. On average, smallholders have higher production probability risks than market probability risks. Schemed production risks are significantly higher than the independent smallholders, while market risks are low for both the schemed and independent smallholders, although schemed smallholders have a slightly higher risk than the independent smallholders. Therefore, the maximum loss of the schemed smallholders is higher than the independent ones. 
Smallholders also have a low risk impact. The IDR 3,008,500 (USD217.50) and IDR975,591 (USD70.53) yearly loss impact for schemed and independent are only $17.930 \%$ and $4.934 \%$ of their total yearly average income, respectively. The schemed and independent income are IDR16,763,412 (USD1,211.93) per year and IDR19,726,333 (USD1,426.14) per year or IDR1,396,951 (USD100.99) per month and IDR1,643,861(USD118.84) per month, respectively. In fact, the North Sumatra minimum wage(Upah Minimum Provinsi/UMP) is IDR2,132,188 (USD154.15) per month, which is the minimum salary for workers that do not have the risk and uncertainty. With an average size of 2.89 ha and $2.73 \mathrm{ha}$, the schemed and independent smallholders earn IDR4,040,948 (USD292.14) per month and IDR4,498,153 (USD325.19) per month respectively. The average income of schemed smallholders is higher than that of the independent ones, because their oil palm trees of schemed smallholders are dominated by old trees. $57 \%$ of the trees of schemed smallholders are classified in the above 21 year-old group, while those of the independent smallholders are dominated by the 10-21 year-old group. In the government FFB pricing rules, the selling price of the old tree yield is lower as the oil content is also lower. In addition, the average FFB productivity of the 10-21 year old trees are higher than those from the older ones. Many smallholders are still unwilling to replant their old trees, while in fact productivity and selling price have decreased, and harvesting cost has increased. If such condition continues, the sustainability of smallholdings might be at risk.

\section{Managerial Implication}

Stakeholders and the Indonesian Government need to optimize the potentials by increasing yields and selling prices. Yield increase can be achieved by using certified and legitimate seeds, and by improving Good Agricultural Practice (GAP). Higher selling prices can be received by maintaining the oil extraction rate and improving market access through integration between smallholders and the companies. At the same time, the improvement of the market access of smallholders may also increase their market, demanding the improvement in the managerial and entrepreneurial skills of smallholders as well.

\section{CONCLUSIONS AND RECOMMENDATIONS}

\section{Conclusions}

The results and discussions show that oil palm smallholders face low risk probability and impact. However, this mainly stems from the extremely low input expenditure, which leads to low productivity. As thresholds of this study used the level of production and price of BEP, such condition leads to low risks in both production and market risks.

\section{Recommendations}

Future study using different approaches of threshold levels are needed to address such a condition. Another option is using variances as the measurement of risks. Chaves and Shi (2015) called inputs that increase output variance as risk-increasing, while those reduce the output variance as risk-decreasing. In addition, many schemed smallholders receive low prices as their FFB is harvested from old trees. This might harm the sustainability of oil palm smallholdings in the future. With more than $40 \%$ share of the total oil palm plantation in Indonesia, this could also harm the whole industry. Therefore, replanting and maintaining the oil palm tree age composition among the Indonesian oil palm plantation is of utmost importance.

\section{ACKNOWLEDGEMENT}

Funded by Lembaga Penelitian Universitas Sumatera Utara in accordance with TALENTA Universitas Sumatera Utara Research Contract 2018 No 2590/ UN5.1.R/PPM/2018 dated 16 March 2018.

\section{REFERENCES}

Aimin, H. 2010. Uncertainty, risk aversion and risk management in agriculture. Agriculture and Agricultural Science Procedia 1:152-156.

Asfaha T, Desmond AF, Hailu G and Singh R. 2014. Statistical evaluation of value at risk models for estimating agricultural risk. Journal of Statistical and Econometric Methods 3(1):13-34.

Benny WP, Putra SET, Supriyanta. 2015. The productivities responses of oil palm (Elaesis Guineensis Jacq) to variation of climate elements. Vegetalika 4(4): 21-34. 
Chalil D, Barus R. 2016. Improving oil palm smallholders participation in global market to strengthening Indonesian agribusiness rural development. In Proceeding International Conference Strengthening Indonesian Agribusiness: Rural Development and Global Market Linkages; Bogor, April 25 - 26th 2016, Bogor : Department of Agribusiness, Faculty of Economics and Management, Bogor Agricultural University. p $283-294$.

Chalil D, Barus R. 2017. Analisis Elastisitas Transmisi Sawit Indonesia ke Pasar Pakistan. Research Report. TALENTA Fund.

Directorate General of Estate Crops. 2017. Tree Crop Estate Statistics of Indonesia 2015-2017: Palm Oil. Jakarta: Secretariat of Directorate General of Estate Crops, Directorate General of Estate Crops, Ministry of Agriculture.

Girdžiūtè L. 2012. Risks in agriculture and opportunities of their integrated evaluation. Procedia - Social and Behavioral Sciences 62(2012):783-790. doi: 10.1016/j.sbspro.2012.09.132.

Hansson. 2010. Risk: Objective or subjective, fact or value. Journal of Risk Research 13(2):231-237. https://doi.org/10.1080/13669870903126226.

Howarth. 1988. The relationship between objective risk, subjective risk and behaviour. Ergonomics 31(4):527-535. https://doi. org/10.1080/00140138808966697.

Kementerian Koordinator Bidang Perekonomian. 2011. Masterplan Percepatan dan Perluasan Pembangunan Ekonomi Indonesia. Jakarta: Kementerian Koordinator bidang Perekonomian Indonesia.

Köprülü O. 2014. Decision-making process and risk analysis of agricultural market economy in Turkey: A case study from Kalecik region wine producers. European Journal of Research on Education 2(Special Issue 6): 55-61.

Lake S, Rosenbarger A, Winchester C. 2016. PALM Risk Assessment Methodology: Prioritizing Areas, Landscapes, and Mills. Technical Note. Washington, DC : World Resources Institute. Available online at: https://www.wri.org/ sites/default/files/Palm_Risk_Assessment Methodology_Prioritizing_Areas_Landscapes_ And_Mills.pdf.

Ogurtsov VA, Van Asseldonk, MPAM, Huirne, RBM. 2008. Assessing and modelling catastrophic risk perceptions and attitudes in agriculture: a review. Wageningen Journal of Life Sciences 56(1-2): 39-58. https://doi.org/10.1016/S15735214(08)80016-4.

[PUSDATIN] Pusat Data dan Informasi Pertanian. 2015. Analisis PDB Sektor Pertanian Tahun 2013. Jakarta: Pusat Data dan Sistem Informasi Pertanian, Kementerian Pertanian.

Riwthong S, Schreinemachers P, Grovermann C, Berger T. 2017. Agricultural commercialization: Risk perceptions, risk management and the role of pesticides in Thailand. Kasetsart Journal of Social Sciences 38:264-272. http://dx.doi. org/10.1016/j.kjss.2016.11.001.

Santeramo FG, Capitanio F, Adinolfi F. 2014. Integrating agricultural risks management strategies in selected EU partner countries: Syria, Tunisia, Turkey. Romanian Journal of European Affairs 14(3):22-35. https://doi.org/10.2139/ ssrn.2491415.

Saragih IR, Chalil D, Ayu SF. 2018. Analisis risiko produksi padi dalam pengembangan asuransi usahatani padi (AUTP) (Desa Panca Arga, Kecamatan Rawang Panca Arga, Kabupaten Asahan). AGRISEP 17(2):187-196. https://doi. org/10.31186/jagrisep.17.2.187-196.

Suharyanto, Rinaldy J, Arya NN. 2015. Analisis risiko produksi usahatani padi sawah di Provinsi Bali. AGRARIS: Journal of Agribusiness and Rural Development Research 1(2):70-77. https://doi. org/10.18196/agr.1210.

Turvey et al. 2013. Subjective risks, objective risks and the crop insurance probability in in Rural China. The Geneva Papers 38:612-633. https:// doi.org/10.1057/gpp.2012.42.

van Dijk, MP. 2012. Sustainability, fair play and free trade in the modern world, Partnerships for the development of sustainability in Malaysia's palm oil sector. Journal of Oil Palm and the Environment 3:75 - 82.

Wang E, Yu Y, Little BB, Li Z. 2010. Crop insurance premium design based on survival analysis model. Agriculture and Agricultural Science Procedia 1:67-75. https://doi.org/10.1016/j. aaspro.2010.09.009.

Yan B, Wang X, Shi P. 2017. Risk assessment and control of agricultural supply chains under internet of things. Agricultural Economics Research, Policy and Practice in Southern Africa 56(1):1-12. https://doi.org/10.1080/0303 1853.2017.1284680. 